\title{
FUNGAL SPORE TRANSPORT THROUGH A BUILDING STRUCTURE
}

\author{
M Airaksinen ${ }^{1}, \mathrm{~J} \mathrm{Kurnitski}^{1}$, P Pasanen $^{2}$, O Seppänen ${ }^{1}$ \\ ${ }^{1}$ Helsinki University of Technology, Laboratory of Heating, Ventilating and Air-Conditioning, Finland \\ ${ }^{2}$ University of Kuopio, Department of Environmental Sciences, Finland
}

\begin{abstract}
The study carried out laboratory measurements with a full-scale timber frame structure to determine penetration of inert particles with size distribution from 0.6 to $4 \mu \mathrm{m}$ and spores of Penicillium and Cladosporium through the structure. Pressure difference over and air leakage through the structure were varied. Measurements at moderate pressure differences resulted in the penetration factors within the range of 0.05 to 0.2 for inert particles, and indicated also the penetration of fungal spores through the structure. The measurements showed that the penetration was highly dependent on pressure difference over the structure but not on holes in surface boards of the structure. The results show that surface contacts between the frames and mineral wool may have a significant effect on penetration. The penetration was approximately constant within particle size rage of 0.6-2.5 $\mu \mathrm{m}$, but particles with diameter of $4.0 \mu \mathrm{m}$ did not penetrate through the structure at all even at a higher-pressure difference of $20 \mathrm{~Pa}$, except in the case of direct flow-path through the structure. Results have important consequences for practical design showing that penetration of fungal spores through the building envelope is difficult to prevent by sealing. The only effective way to prevent penetration seems to be balancing or pressurizing the building. In cold climates, moisture condensation risk should be taken into account if pressure is higher indoors than outdoors. Determined penetration factors were highly dependent on the pressure difference. Mechanical exhaust ventilation needs a special consideration as de-pressurizing the building may cause health risk if there is hazardous contamination in the building envelope exists.
\end{abstract}

\section{PRACTICAL IMPLICATIONS}

Measurements at moderate pressure differences allowed determining penetration factors within the range of 0.05 to 0.2 for inert particles in a size range of $0.6-2.5 \mu \mathrm{m}$ and indicative results with fungal spores confirmed the penetration through the wooden floor structure. Both measurements showed that the penetration was highly dependent on pressure difference and not dependent on holes in surface boards of the structure. The results are likely to show that surface contacts of mineral wool with other building elements may have an important role on the penetration.

\section{INDEX TERMS}

Microbes, Particles, Transport to Indoors, Crawl Space

\section{INTRODUCTION}

Moisture accumulation into building structures or material may lead to microbial growth on materials, subsequent microbial emissions and other contamination of buildings. In epidemiological population studies, moisture damage and microbial growth in buildings have been associated with a number of health effects including respiratory symptoms and diseases and other symptoms (Hyvärinen 2002, Nevalainen et al. 1998, Peat et al. 1998, Verhoeff and Burge 1997). The health effects associated with moisture damage and microbial growth seem to be consistent in different climates and geographical regions (Ellringer et al. 2000, Hunter et al.1988, Li and Kuo 1994, Nevalainen et al. 1991).

This study focused on transport of inert particles and fungal spores through a building structure to indoor. Microbiologically clean buildings probably do not exist as some contamination in the structures build up already during the construction phase. In the case of moisture damages, even after repairs, significant amount of contaminated materials can remain in structures (Nguyen Thi et al. 2000). Therefore, potential transport of pollutants from and through structures has a great importance in respect of design and construction of buildings. It is important to know which factors affect release and penetration of pollutants and possible measures, such as

\footnotetext{
* Corresponding author email: Miimu.Airaksinen@Optiplan.fi
} 
sealing and pressurizing, to avoid it. This study used a laboratory setup with a common building structure having high concentration of particles in one side to study the penetration of particles. Particle type, air leakage and pressure difference were varied.

A structure similar to wooden floor used in connection with crawl space foundation was selected to the study. The level of fungal spores in the crawl space might be several orders of magnitude greater than indoors. In the contaminated crawl spaces, the spore densities may be in a range of $10^{3}-10^{5}$ colony-forming units per gram (cfu/g) of material of wood-based boards and on timber. Under heavy fungal colonization, airborne spore concentrations were up to $10^{3}-10^{4} \mathrm{cfu} / \mathrm{m}^{3}$ (Kurnitski and Pasanen 2000, Pasanen et al. 2001).

Residential buildings often have mechanical exhaust ventilation where intake air comes through inlets and cracks, Figure 1. In cold climates, inlets may cause draft in winter and consequently are often closed resulting in higher under-pressure indoors and increased infiltration through cracks.

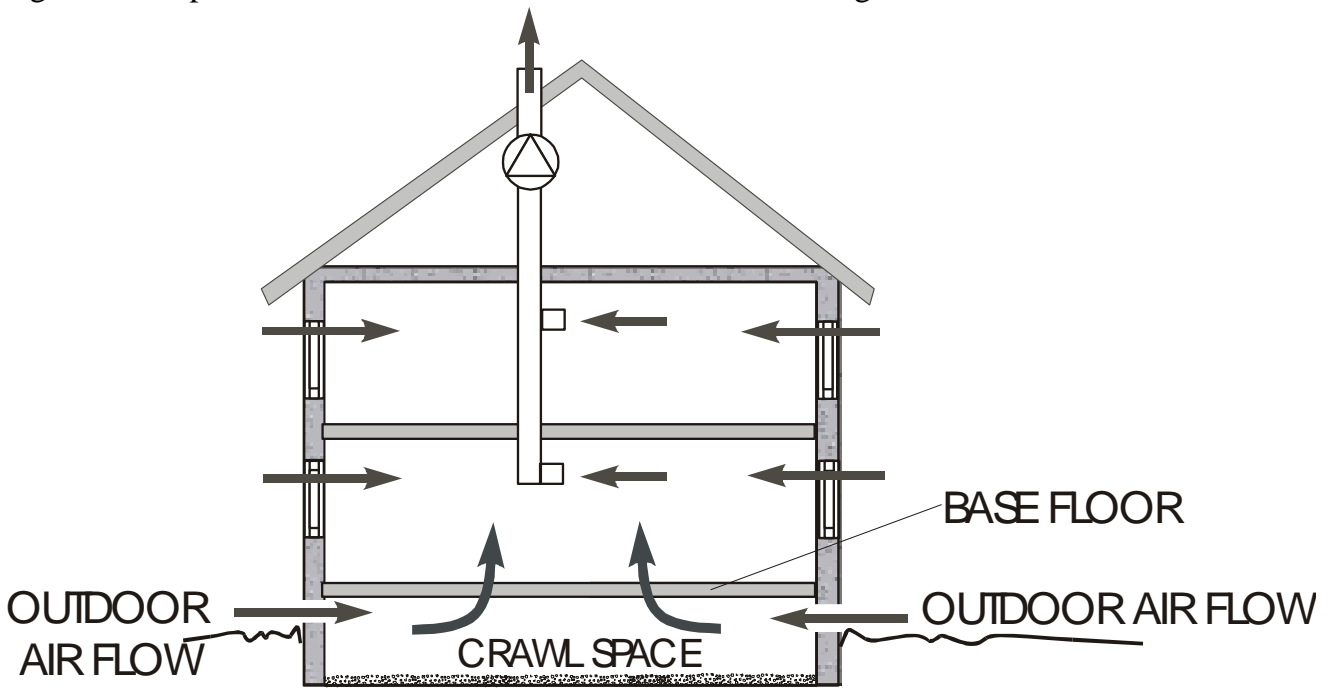

Figure 1 Possible flow paths in an apartment building with mechanical exhaust ventilation and crawl space

Typical indoor under-pressures with mechanical exhaust ventilation are within the range of 5-20 Pa. A field study (Kurnitski 2000) showed high air flow rates through leaks in the floor to the apartment at the pressure difference of around 6 or $15 \mathrm{~Pa}$ depending on the speed of exhaust fan. Field measurements (Airaksinen et al. 2003, Mattson et al. 2002) have shown evidence of fungal spores transported from crawl space to indoors. In a review (Hyvärinen 2002), concentrations of viable fungi varied in the indoor air of residental buildings between $10-100000 \mathrm{cfu} / \mathrm{m}^{3}$, with typical range between 100-10000 cfu/ $\mathrm{m}^{3}$. Lower levels were reported in winter in cold climate (Reponen et al. 1991) but also in subtropical climate (Kuo and Li 1994).

Moisture and mold problems in buildings are associated with health effects of both adults and children occupying these buildings (Peat et al. 1998, Verhoeff and Burge 1997). However, it is not only the moisture and microbes which are causing problems, but also the exposure to fine particles. According to recent research, particles causing health effects are of the size of PM 2.5 (Katsouyanni et al. 2001, Samet et al. 2000). It is still unclear what is causing the health effects of particles, but it seems that the type of the particles has some role. According to studies (Laden et al. 2000, Tiittanen et al. 1999), the dust of sand is not as harmful as the same size of particles originating from fuels. About 70-90\% of viable fungi in indoor air have been estimated to be in the respirable size fraction $(<4.7 \mu \mathrm{m})$ (DeKoster and Thorne 1995, Li and Kuo 1994). The median aerodynamic diameter is typically 2-3 $\mu \mathrm{m}$ for fungi in the indoor air (Macher et al. 1991, Reponen 1995), also the highest concentrations of airborne viable fungi are usually in the size range of $1-3 \mu \mathrm{m}$.

Many studies have been done to estimate the penetration of particles through cracks. Vette et al. (2001) report penetration factors 0.5-0.8 for particles in a size range of 0.5-2.5 $\mu \mathrm{m}$. Mosley et al. (2001) have found that at a pressure of $5 \mathrm{~Pa} 40 \%$ of $2 \mu \mathrm{m}$ particles and $<1 \%$ of $5 \mu \mathrm{m}$ particles penetrate through horizontal slits of height $0.508 \mathrm{~mm}$. In a study (Liu and Nazaroff 2001) particles of $0.1-1.0 \mu \mathrm{m}$ are predicted to have the highest penetration efficiency, nearly unity for crack heights of $0.25 \mathrm{~mm}$ or larger at pressure difference of $\geq 4 \mathrm{~Pa}$. These results are important since the peak of the size distribution of fungal spores is often between 1-3 $\mu \mathrm{m}$ being very 
suitable for penetration. However, there is only a limited number of studies about structures typically used in buildings. Liu and Nazaroff (2001) predict by a simulation model that penetration through mineral wool insulation is negligible. In reality, the mineral wool insulation is seldom perfectly installed, and timber frame structures are in respect of particle transport a combination of cracks, surface contacts and mineral wool.

\section{METHODS}

Ventilation rate of a building affects indoor particle concentrations, and as the fluxes from indoor to outdoor and outdoor to indoor are typically different, indoor air might become contaminated from other sources than outdoors, such as sources from crawl space or from contaminated building materials. Indoor concentrations are reduced by deposition and increased by re-emission of deposited material. The amount of deposited material depends e.g. on deposition rate, re-emission rate and the cleaning frequency. The experiments in laboratory were designed to simulate the entry of particles through building envelopes when all the windows and doors are closed. To measure the particle penetration a full-scale floor structure was built in the laboratory. The floor was located between two chambers corresponding to indoors crawl space. Inert particles and in the second part of the measurements fungal spores were generated to the crawl space chamber. Concentrations of particles/fungal spores were measured and as the air flow through the structure was measured the penetration could be defined.

\section{Penetration factor}

In this study the penetration factors for inert particles were calculated from the mathematical model given by Kulmala et al. (1999)

$$
V \frac{d C_{1}}{d t}=s_{f} \cdot \dot{V}_{2} \cdot C_{2}-\dot{V}_{1} \cdot C_{1}-a \cdot C_{1} \cdot V+r e \cdot B \cdot V+Q
$$

where $\quad V$ is the volume of the room $\left(\mathrm{m}^{3}\right), C_{l}$ the particle concentration in $\mathrm{CH} 1\left(\mathrm{~m}^{-3}\right), t$ time $(\mathrm{s}), s_{\mathrm{f}}$ penetration factor from $\mathrm{CH} 2$ to $\mathrm{CH} 1(-), V_{2}$ air flow from $\mathrm{CH} 2$ to $\mathrm{CH} 1\left(\mathrm{~m}^{3} \mathrm{~s}^{-1}\right), V_{1}$ air flow from $\mathrm{CH} 1$ to outdoors $\left(\mathrm{m}^{3} \mathrm{~s}^{-1}\right)$, $C_{2}$ the particle concentration in the $\mathrm{CH} 2\left(\mathrm{~m}^{-3}\right), a$ deposition rate $\left(\mathrm{s}^{-1}\right)$, re re-emission rate $\left(\mathrm{m}^{-1} \mathrm{~s}^{-1}\right), B$ particle surface accumulation on indoor surfaces $\left(\mathrm{m}^{-2}\right), Q$ sink or source of particles indoors $\left(\mathrm{s}^{-1}\right)$. The deposition rate was calculated from

$a=v_{d} \cdot \frac{A}{V}$

where $\quad v_{d}$ is the deposition velocity $\left(\mathrm{ms}^{-1}\right)$, and $A$ the total indoor surface area including furniture etc. $\left(\mathrm{m}^{2}\right)$.

Particle surface accumulation on indoor surfaces was calculated from

$$
\frac{d B}{d t}=(a \cdot I-r e \cdot B) \cdot \frac{V}{A}
$$

Since the measurements were done in the test chambers, the re-emission rate was assumed to be zero.

In recent studies of buildings or room-sized chambers, the reported deposition velocities had a wide range (Lai 2002). Thus, there is considerable uncertainty in the typical values of deposition velocities for buildings. In this study the deposition velocity used was adapted from results reported in Xu et al. (1994), Thatcher et al. (2002), and is extrapolated with theoretical predictions of Lai and Nazaroff (2000), the same deposition velocity is used also in Fisk et al. (2002). Deposition velocity, Equation (4), used here is based on a combination of measured data from full size rooms and extrapolations consistent with theoretical predictions, and it is valid for particle diameters between $0.3-8 \mu \mathrm{m}$, Figure 2 .

$v_{d}=3 \cdot 10^{-5} \cdot\left(d_{p} \cdot 10^{6}\right)^{1.58}-1 \cdot 10^{-6}$

where $d_{p}$ is the diameter of the particle $(\mu \mathrm{m})$. 


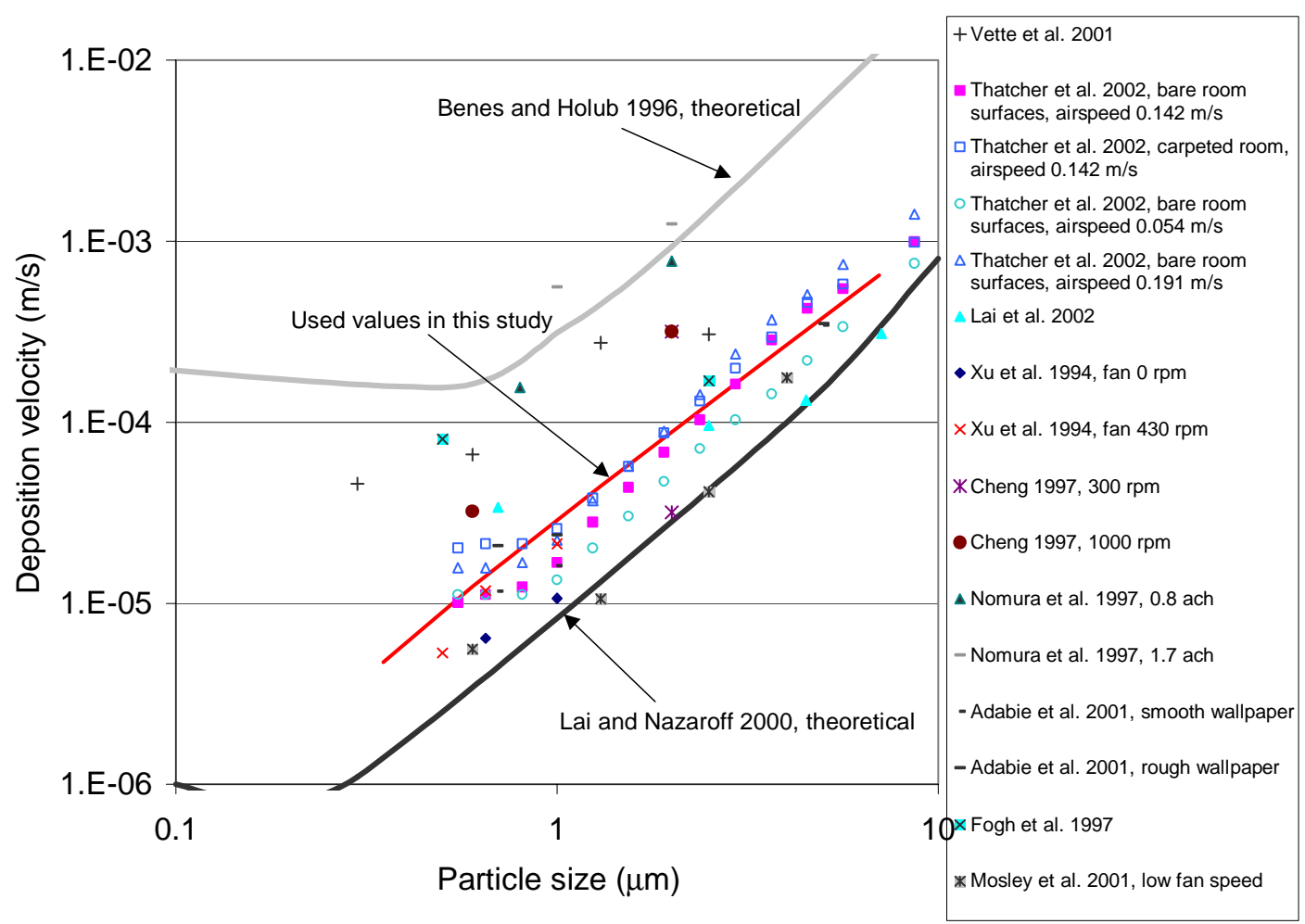

Figure 2 Average deposition velocities measured in several studies, and the deposition velocity used in this study. The deposition velocity of the theoretical model of Beneš and Holub (1996) is a function of surface-volume-ratio, Brownian diffusion coefficient, thickness of boundary layer and parameters $k_{e}$ to characterize the magnitude of turbulent flow and parameter $n$ to capture the effect of transverse distance from a surface. Originally the model did not include the gravitational sedimentation factor, thus, it is accurate only for small particles. However, a simple sedimentation term is added to their model by Nomura et al. (1997), which extended the size range of particles in micrometer size range. The used parameter values, derived by Nomura et al. (1997) were: $k_{e}=1.66 \mathrm{~s}^{-1}, n=2.6$. The other theoretical model by Lai and Nazaroff (2000), also takes into account Brownian diffusivity, surface and volume areas, particle diameter and kinematic viscosity, but the describing parameter in the equation of deposition velocity is friction velocity $u^{*}$. The used friction velocity here is $1 \mathrm{~cm} / \mathrm{s}$. According to Lai and Nazaroff (2000) their model agrees with Crump And Seinfield (1981) model with parameters $n=2.94$ and $k_{e}=0.0305 \mathrm{~cm}^{-0.94} \mathrm{~s}^{-1}$, when friction velocity $1 \mathrm{~cm} / \mathrm{s}$ is used.

Since the penetration factor is strongly dependent on deposition velocities the factors were also calculated for the highest and lowest measured values presented in recent studies, Table 1 Since most of the referred studies reported deposition loss time, only Fogh et al. (1997) reported deposition velocity, the results in Table 1 and Figure 2 were transformed to average deposition velocity. If the measured particle size in other studies was different from the size used in this study, the deposition velocities were extrapolated to the particle size used in this study. The results from Nomura et al. (1997), Cheng (1997) and Vette et al. (2001) are clearly higher than those from the others. In studies by Cheng (1997) and Nomura et al. (1997) the chambers were smaller than room size, and thus, they were excluded. In Vette et al. (2001) a single detached residence was measured and the measured results were clearly higher at particle sizes $>0.6 \mu \mathrm{m}$ than the calculated with model suggesting an additional sink. Also this study was excluded as it most probably overestimates the deposition velocity in laboratory conditions.

Table 1 The highest and lowest average deposition velocities used in calculations.

\begin{tabular}{|c|c|c|}
\hline Particle size $(\boldsymbol{\mu m})$ & Lowest deposition velocity $(\mathbf{m} / \mathbf{s})$ & Highest deposition velocity $(\mathbf{m} / \mathbf{s})$ \\
\hline 0.6 & $5.6 \mathrm{E}-6^{(1}$ & $3.2 \mathrm{E}-5^{(3}$ \\
\hline 1.3 & $1.1 \mathrm{E}-5^{(1}$ & $5.5 \mathrm{E}-5^{(2}$ \\
\hline 2.5 & $4.1 \mathrm{E}-5^{(1}$ & $1.7 \mathrm{E}-4^{(4}$ \\
\hline 4.0 & $4.8 \mathrm{E}-5^{(2}$ & $3.4 \mathrm{E}-4^{(5}$ \\
\hline \multicolumn{2}{|c|}{${ }^{3}$ Cheng 1997} \\
${ }^{1}$ Mosley et al. 2001 & ${ }^{2}$ Lai et al. 2002 & \\
${ }^{4}$ Fogh et al. 1997 & ${ }^{5}$ Thatcher et al. 2002
\end{tabular}


The air flow to chamber $2(\mathrm{CH} 2)$ and from chamber $1(\mathrm{CH} 1)$ were defined by measuring air flow velocities. The penetration factor for inert particles was calculated from the values when both chambers had reached steady state.

For Penicillium and Cladosporium it was not possible to achieve steady state concentrations with equipment used and, therefore, the penetration factor was estimated as a percentage of the particles penetrated through the structure.

$s_{f, \%}=\frac{C_{1}}{C_{2}} \cdot 100$

\section{Chamber description}

To measure the particle penetration, a full-scale floor structure with dimensions of 2.2 by $2.2 \mathrm{~m}$ was built in the laboratory. The floor was located between two chambers; $\mathrm{CH} 1$ corresponds to indoors and $\mathrm{CH} 2$ to crawl space as shown in Figure 3. As the gravitational force has minor importance for small particles, the floor was turned $90^{\circ}$ for practical reasons. The air was exhausted only from $\mathrm{CH} 1$ forcing the flow through the floor. To control the pressure difference between chambers a supply airflow rate to $\mathrm{CH} 1$ was controlled. The supply air to $\mathrm{CH} 2$ was filtered by using HEPA filter (high efficiency particulate air), and it flowed through a diffuser to ensure that the supply air is fully mixed in $\mathrm{CH} 2$. To ensure that the particles were fully mixed in the air of $\mathrm{CH} 2$ the concentration of particles was measured at three different heights $(70 \mathrm{~cm}, 110 \mathrm{~cm}$ and $190 \mathrm{~cm}$ from the bottom of $\mathrm{CH} 2$ ). Air flow to $\mathrm{CH} 2$ was measured by using air velocity measurements and the exhaust from $\mathrm{CH} 1$ was measured with air duct measuring ring. The supply to $\mathrm{CH} 1$, which was mainly zero, was measured with the measuring ring. The pressure difference was measured by differential pressure transmitters, Furness Controls FCO $44 \pm 50 \mathrm{~Pa}$, continuously in 60 seconds interval between chamber 1 and laboratory hall, and between chamber 2 and laboratory hall, and the pressure difference between chambers were calculated from measured results.

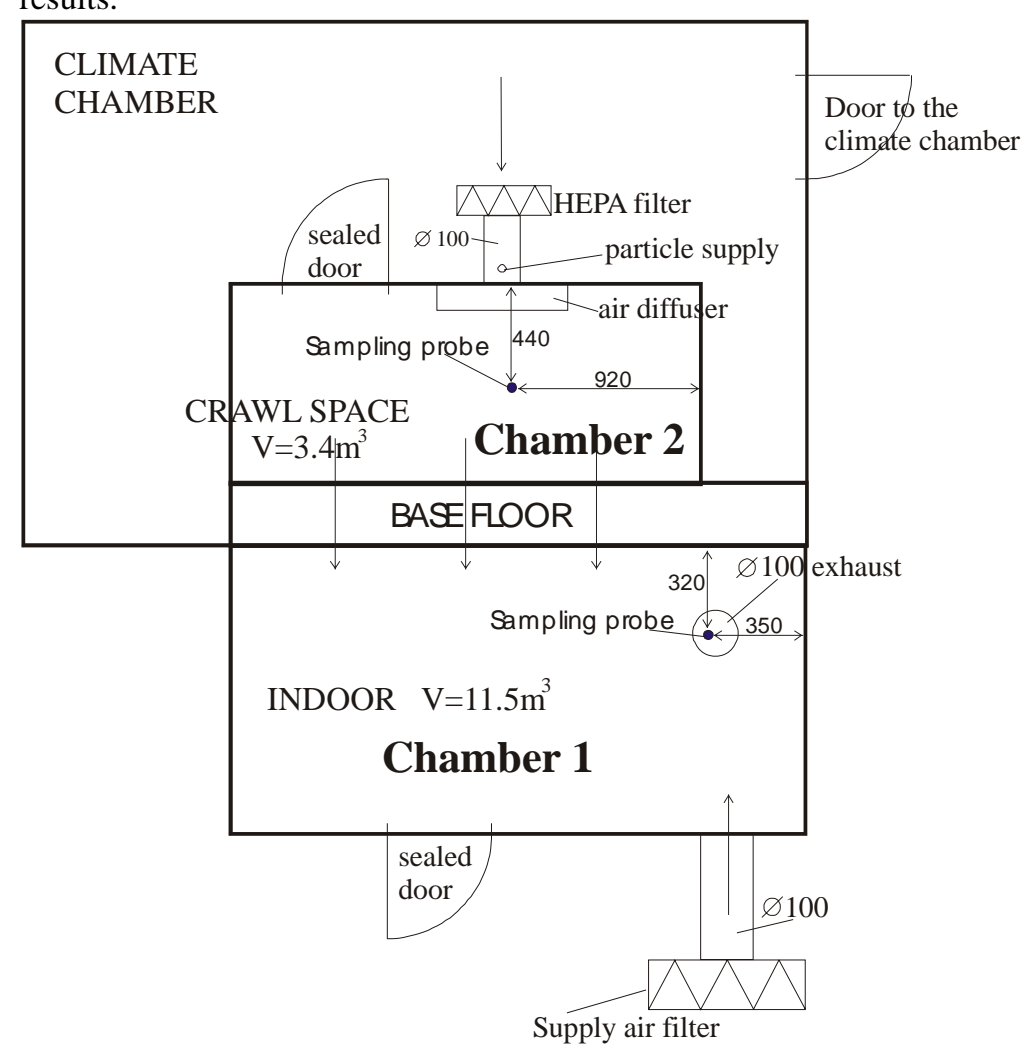

Figure 3 Chamber 1 and 2, and the placements of sampling probes.

Four different variations of a wooden floor structure were studied. The floor had $20 \mathrm{~cm}$ mineral wool insulation (rock wool with volume weight of $30 \mathrm{~kg} \mathrm{~m}^{-3}$ ), $22 \mathrm{~mm}$ chipboard in the indoor chamber side and $13 \mathrm{~mm}$ porous fibreboard in $\mathrm{CH} 2$ side Figure 4. The joints between boards were installed as tight as possible, and the joints 
between wooden base floor and chamber walls were well sealed with Sikaflex-221 polyurethane-based adhesivesealant (Sika AG, Bar, Switzerland). Air leakage of the wooden floor was measured according to EN 13829 (2000) at $50 \mathrm{~Pa}$ under pressure. The measured air leakage values varied with different penetrations as shown in Table 2. The shown air leakage in Table 2 illustrates a leakage of a typical apartment $\left(10 \times 10 \times 2.5 \mathrm{~m}^{3}\right)$, i.e. the whole envelope of the apartment is assumed to be as air tight as the floor structure measured in laboratory. For residential and apartment buildings, often an air leakage value of 1-2 ach is considered as a air tight building (Persily 1998).

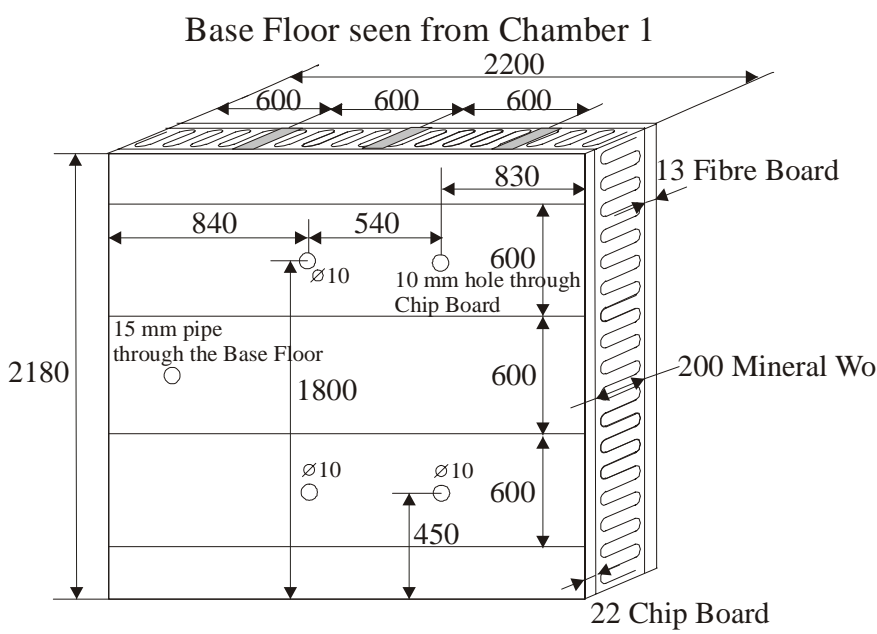

Base Floor seen from the Chamber 2

Figure 4 The construction of the floor (dimensions in $\mathrm{mm}$ )

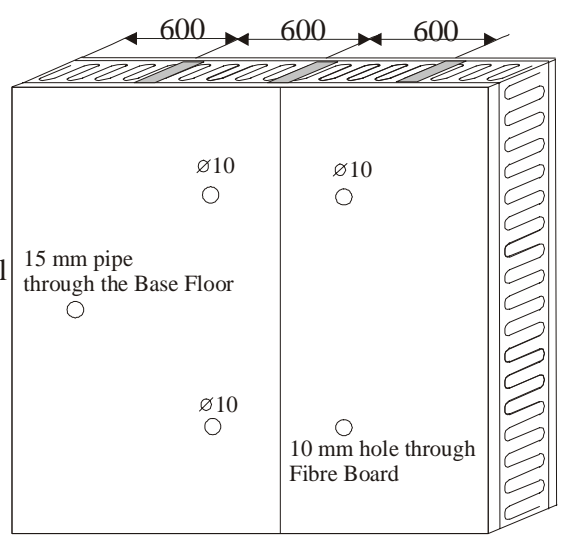

Table 2 Studied floor structures

\begin{tabular}{|c|c|c|c|}
\hline \multirow[t]{2}{*}{ Floor } & \multirow[t]{2}{*}{ Description } & \multicolumn{2}{|c|}{ Air leakage } \\
\hline & & $\mathrm{m}^{3} / \mathrm{h}, \mathrm{m}^{2}$ & $\mathrm{ach}^{1)}$ \\
\hline No penetrations & No penetrations nor holes in the floor & 0.88 & 1.0 \\
\hline $\begin{array}{l}\text { Capped } \varnothing 15 \mathrm{~mm} \\
\text { pipe }\end{array}$ & $\begin{array}{l}15 \mathrm{~mm} \text { copper pipe penetrating the floor, to simulate } \\
\text { that the sealing of the construction was not made in } \\
\text { accordance with the best practice. Copper pipe itself } \\
\text { capped, thus no particle could flow through pipe. }\end{array}$ & 0.83 & 1.0 \\
\hline $\begin{array}{l}\text { Ø10 mm holes in the } \\
\text { surfaces }^{2)}\end{array}$ & $\begin{array}{l}\text { four } 10 \mathrm{~mm} \text { holes both in the fibreboard and } \\
\text { chipboard at opposite locations to each other. The } \\
\text { holes only in the boards, mineral wool insulation } \\
\text { stayed untouched }\end{array}$ & 1.16 & 1.4 \\
\hline $\begin{array}{l}\text { Ø13 mm holes in the } \\
\text { surfaces }^{3)}\end{array}$ & $\begin{array}{l}\text { three } 13 \mathrm{~mm} \text { holes both in the fibreboard and } \\
\text { chipboard at opposite locations to each other. The } \\
\text { holes only in the boards, mineral wool insulation } \\
\text { stayed untouched }\end{array}$ & 2.03 & 2.4 \\
\hline Open $\varnothing 15$ mm pipe & $\begin{array}{l}15 \mathrm{~mm} \text { copper pipe was open, i.e. the air in } \mathrm{CH} 2 \\
\text { could flow through the pipe to } \mathrm{CH} 1\end{array}$ & 1.19 & 1.4 \\
\hline
\end{tabular}

\section{Inert particles}

In the laboratory measurements six different sizes $(0.6 \mu \mathrm{m}, 1.3 \mu \mathrm{m}, 2.5 \mu \mathrm{m}, 4 \mu \mathrm{m}, 7 \mu \mathrm{m}$ and $15 \mu \mathrm{m})$ of inert monodisperse latex (polystyrene) particles produced by Duke Scientific Corporation were generated to the $\mathrm{CH} 2$.

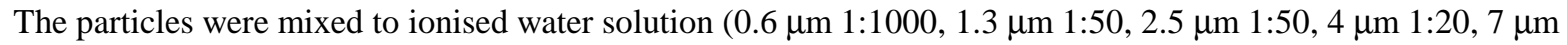
1:7, and $15 \mu \mathrm{m} \mathrm{1:7)} \mathrm{and} \mathrm{they} \mathrm{were} \mathrm{atomised} \mathrm{in} \mathrm{TSI} \mathrm{model} 3076$ atomiser (TSI Gmbh, Aachen, Germany), after which the solution was dried by silica crystals and the electrical charge was neutralized by electrostatic charge neutralizer (TSI model 3012), Figure 5. The pressured air from the net was cleaned and dried before the atomiser. The particle supply flow to the supply air channel of the $\mathrm{CH} 2$ was $3 \mathrm{~L} / \mathrm{min}$. 


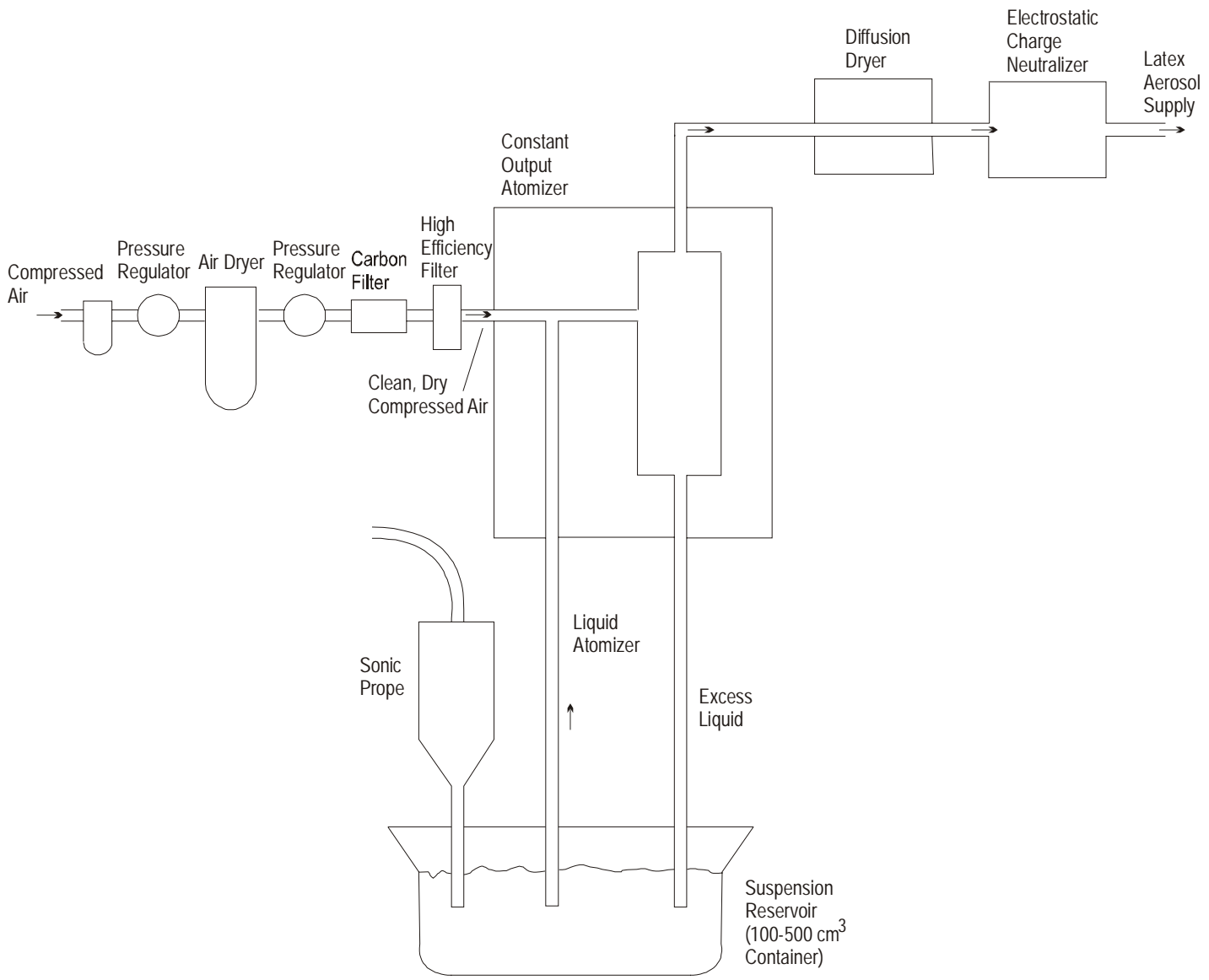

Figure 5 The particle generator system

The pressure difference between the chambers was either around $6 \mathrm{~Pa}$ or $20 \mathrm{~Pa}$. The concentration of particles was measured continuously by using optical particle counter (Climet LI 500, Climet Instrument Company, Redlands, CA, USA) in both chambers. The size ranges of the optical particle counter were $0.3-0.5,0.5-1.0,1-5$, $5-10,10-25$, and $\geq 25 \mu \mathrm{m}$. The pressure differences between $\mathrm{CH} 1, \mathrm{CH} 2$ and laboratory hall were measured, and the air flow to $\mathrm{CH} 2$ and air flow from $\mathrm{CH} 1$ were logged in intervals of one minute.

Background particle concentration and size distributions before the tests were measured inside the test chambers and the surrounding laboratory hall to ensure that the initial levels were low enough to start the tests, Figure 6 (left). The monodispersion of the supplied particles is shown in Figure 6 (right).
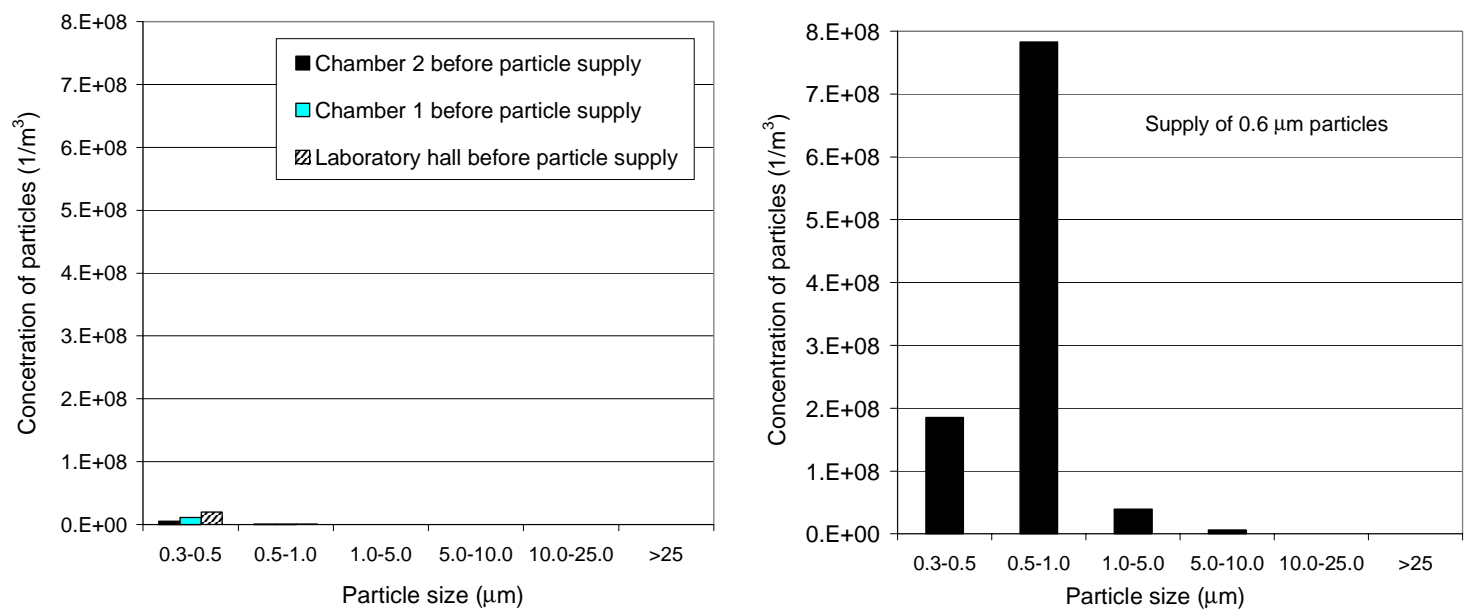

Figure 6 Initial size distribution of particles before particle supply (left) and monodispersion of the particle supply (right) 
In the measurements, the uniform particle supply was continued until the concentrations of particles in both chambers reached the steady state. Then the penetration factor was calculated from the steady state values using Equation 1. The steady state size distributions in both test chambers are shown in Figure 7 thus, the particles supplied may be easily identified. Since the preliminary tests showed good repeatability, the tests were repeated only when the structure was changed.

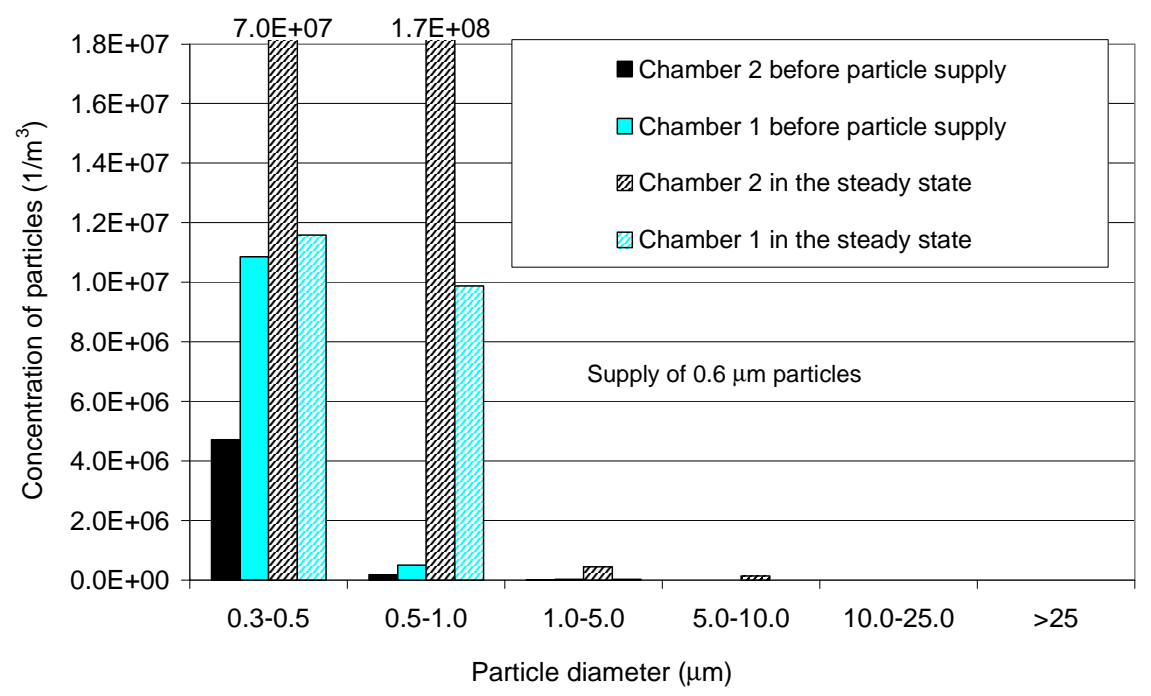

Figure 7 The size distribution of particles before particle supply and in the steady state

\section{Penicillium and Cladosporium}

Spores of Penicillium crustosum and Cladosporium spaerospermum were supplied to $\mathrm{CH} 2$ by using circulating air, thus, the supply of fungal spores did not affect the air change rate of $\mathrm{CH} 2$. The fungi grew on a malt extract agar moulded on the half circle inside a glass tube. The fungal spores were released from the glass tube with an air speed of $7 \mathrm{~m} / \mathrm{s}$. A thin plastic string was used to ease the release of fungal spores from the glass tube. Fungal spores were released through all the measuring time, but as from Figure 8 can be seen the release was strongest during the first 30 minutes. A new cultivated tube was used as a source fungal spores for each measurement. The pressure differences between the chambers were $6 \mathrm{~Pa}$ and $18 \mathrm{~Pa}$.

The concentrations of airborne fungal spores were measured in both chambers by using six-stage cascade Andersen impactors (Andersen Samplers, Inc. 1979); and three samples were taken from both chambers. In $\mathrm{CH} 2$, the first sample was taken 15 min after the supply of particles was started, the second sample was taken 30 min after the first sample and at that time also the first sample from $\mathrm{CH} 1$ was taken. The following samples were taken in $30 \mathrm{~min}$ intervals. The fungal spores were collected on $2 \%$ malt extract agar (MEA). The sampling times are shown in Table 3. The incubation time of the samples was five to seven days at $25^{\circ} \mathrm{C}$. The number of the counted colonies on the were corrected according to Andersen (1958). The concentration of particles was also measured continuously by using optical particle counter in both chambers. The sampling time for optical particle counter was one minute.

Table 3 Sampling times of different measuring cases

\begin{tabular}{|l|l|c|c|c|}
\hline Microbe & Floor & $\begin{array}{c}\text { Pressure, } \\
(\text { Pa })\end{array}$ & $\begin{array}{c}\text { Chamber 2 } \\
\text { samples }\end{array}$ & $\begin{array}{c}\text { Chamber 1 } \\
\text { samples }\end{array}$ \\
\hline Penicillium & $\varnothing 13$ mm holes in the surfaces & 18 & $3 \times 5 \mathrm{~min}$ & $3 \times 10 \mathrm{~min}$ \\
\hline & No penetrations & 18 & $3 \times 1 \mathrm{~min}$ & $3 \times 5 \mathrm{~min}$ \\
\hline & No penetrations & 6 & $3 \times 1 \mathrm{~min}$ & $3 \times 5 \mathrm{~min}$ \\
\hline & $\emptyset 13 \mathrm{~mm}$ holes in the surfaces & 6 & $3 \times 1 \mathrm{~min}$ & $3 \times 5 \mathrm{~min}$ \\
\hline Cladosporium & $\emptyset 13 \mathrm{~mm}$ holes in the surfaces & 6 & $3 \times 1 \mathrm{~min}$ & $3 \times 5 \mathrm{~min}$ \\
\hline & $\emptyset 13 \mathrm{~mm}$ holes in the surfaces & 18 & $3 \times 1 \mathrm{~min}$ & $3 \times 5 \mathrm{~min}$ \\
\hline & No penetrations & 18 & $2 \times 30 \mathrm{~s}, 1 \times 1 \mathrm{~min}$ & $3 \times 1 \mathrm{~min}$ \\
\hline & No penetrations & 6 & $2 \times 30 \mathrm{~s}, 1 \times 1 \mathrm{~min}$ & $3 \times 1 \mathrm{~min}$ \\
\hline
\end{tabular}


It was not possible to achieve steady state concentrations with the equipment used. Unstable supply caused at first high concentration peak, then supply rate decreased and concentration curves look decaying, although the supply was all the time on. The first samples from $\mathrm{CH} 1$ and $\mathrm{CH} 2$ were both taken near the maximum concentration. The behaviour was similar with a lower pressure difference of $6 \mathrm{~Pa}$. Both with Penicillium and Cladosporium the highest numbers of fungal spores were found within the size range of $1-5 \mu \mathrm{m}$ by optical particle counting Figure 9. Spores of Penicillium seem to agglomerate as the number of sizes between $5-$ $10 \mu \mathrm{m}$ was also elevated after supply of fungal spores. The measurements with fungal spores were not repeated.

Penicillium, No penetrations, $18 \mathrm{~Pa}, 1-5 \mu \mathrm{m}$

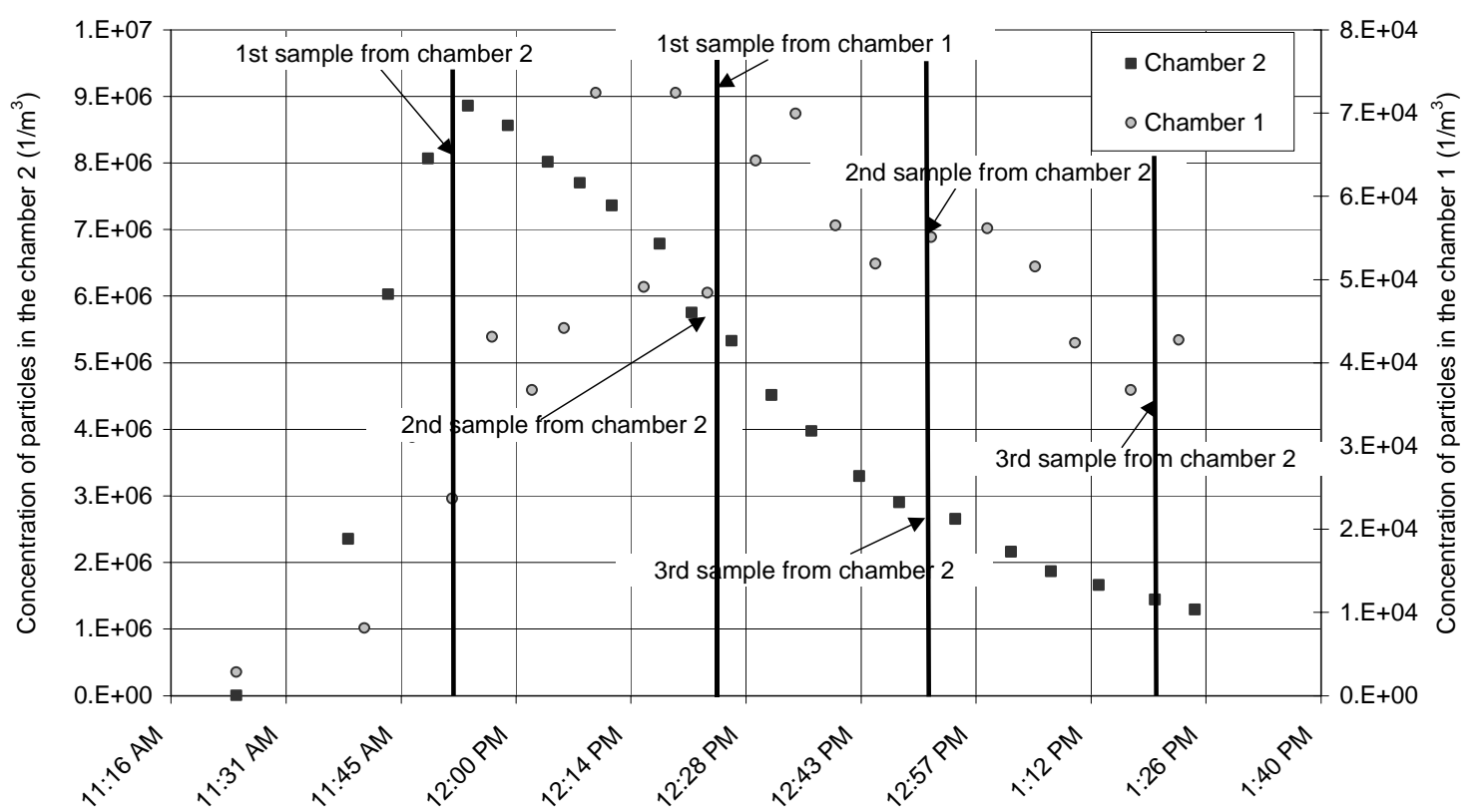

Figure 8 Particle concentrations and the timing of samples for the structure with no penetrations at pressure difference of $18 \mathrm{~Pa}$
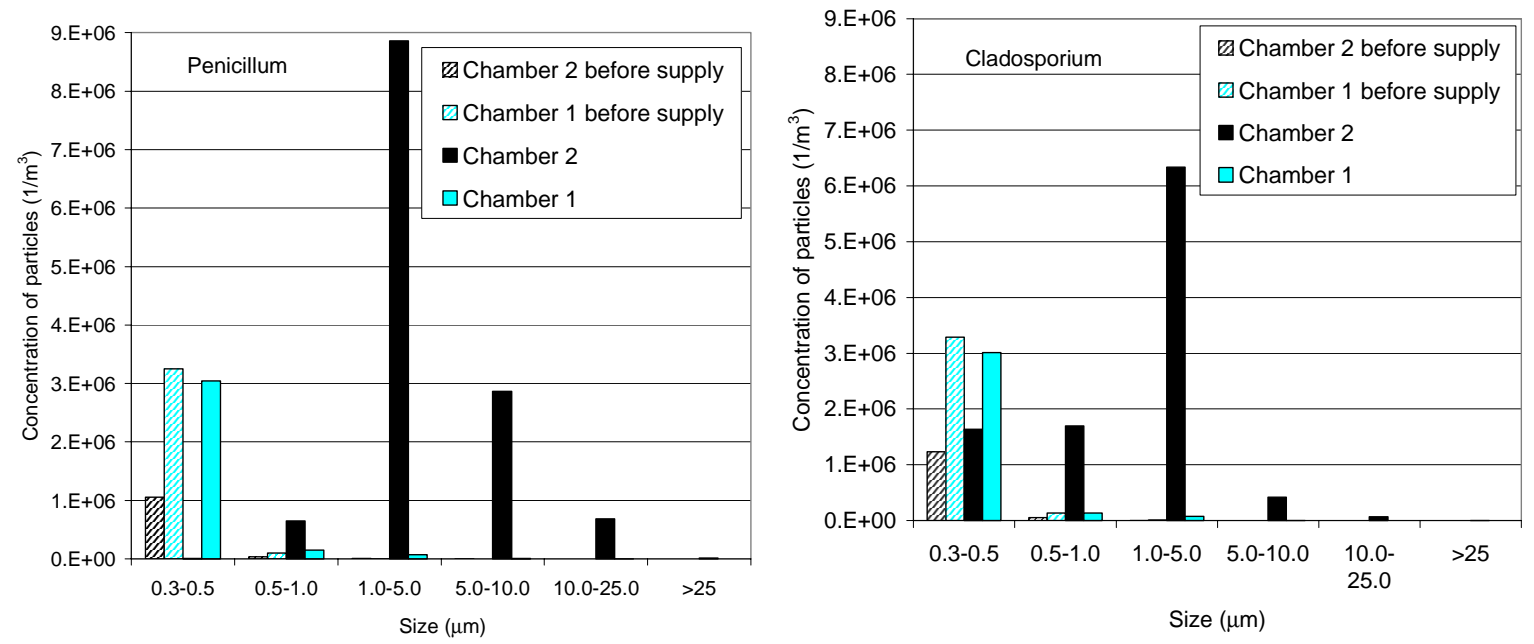

Figure 9 Size distributions in Penicillium (left) and Cladosporium (right) tests before and after the supply of fungal spores by optical particle counting for the structure with no penetrations at pressure difference of $18 \mathrm{~Pa}$

\section{RESULTS}

Penetration through a structure to indoor was first measured with inert particles whose supply, monodispersion and concentrations were relatively easy to control. Constant supply rate led to steady state concentrations on both sides of the studied structure and, thus, penetration factors were possible to derive at different air leakage rates 
and pressure differences. In the case of fungal spores, steady state conditions were not achieved and results only indicate the fact that there occurred penetration.

\section{Inert particles}

The penetration factor $s_{\mathrm{f}}$ was calculated from Equation (1); penetration from the laboratory hall was assumed to be zero, since the chambers were well sealed. The results in Figure 10 show that there are very small differences in respect of the air flow paths of the first three cases for particles of $0.6,1.3$ and $2.5 \mu \mathrm{m}$. Smaller particles show only slightly higher penetration factor. This indicates that holes in the surface boards of the structure (which increase air leakage only from 1 to $1.4 \mathrm{ach}$ ) do not affect penetration of these particles. The material layer unchanged in these cases, mineral wool and probably especially its surface contacts, is likely to dominate the penetration of these particles. The penetration factor 0 for $4 \mu \mathrm{m}$ seems to conform the importance of mineral wool layer (and its installation) for particles. For $4 \mu \mathrm{m}$ particles mineral wool already acts as a perfect filter. The last case with an open pipe through the structure shows completely different performance with much higher penetration factors for all particles. All the results in Figure 10 stress the effect of pressure difference over the structure. Higher pressure difference leads to significantly higher penetration factors for all the structures and particles studied.

As already mentioned, the deposition velocity has a significant effect on the estimation of the penetration factor. In Figure 10 the error bars for the penetration factors were calculated from the lowest and highest deposition velocities from recent studies, shown in Table 1. The difference between the minimum or maximum value and the value used in this study depending on deposition velocity might be as high as $48 \%(2.5 \mu \mathrm{m})$. However, the difference in the value of penetration factor was only 0.01-0.08 depending on the case, except in the case of open pipe at particles $1.3 \mu \mathrm{m}$.

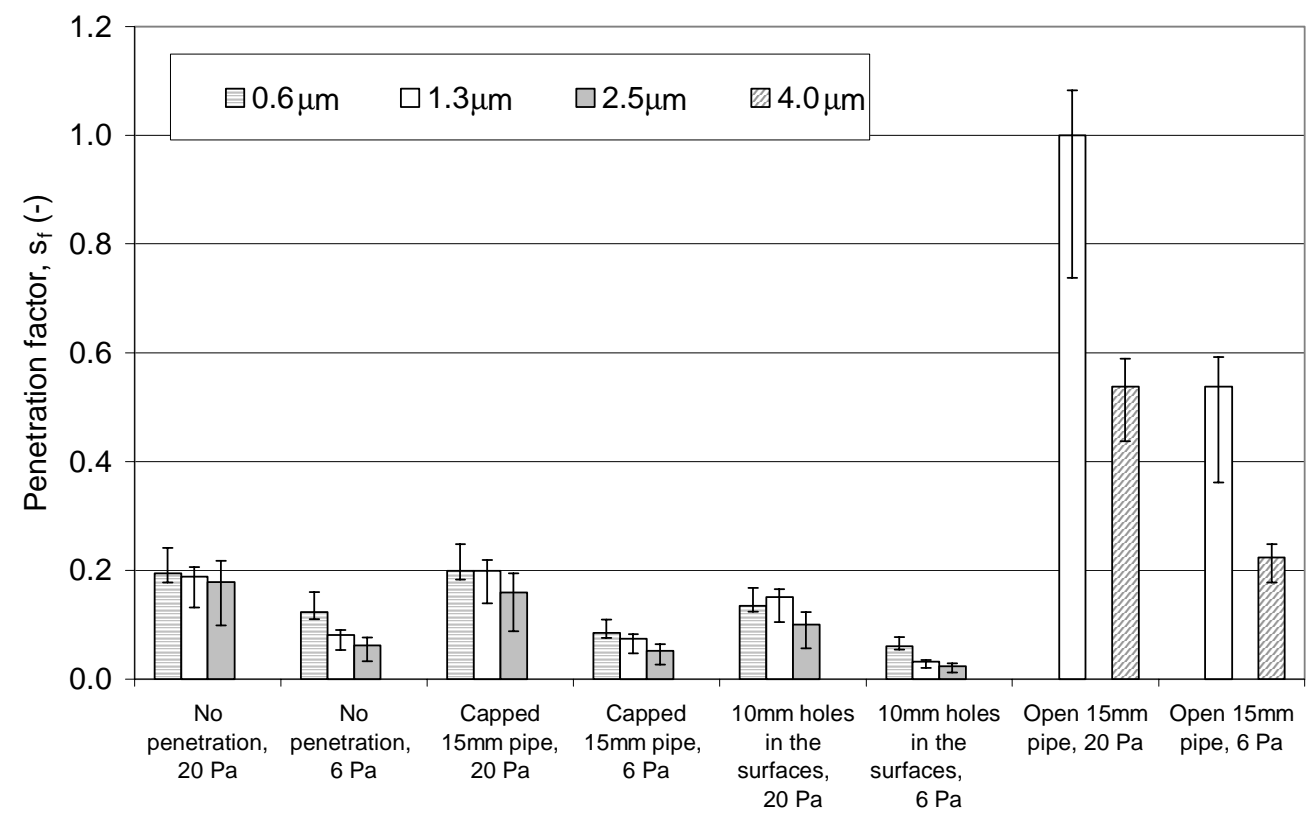

Figure $10 \quad$ Penetration factors calculated with different deposition velocities

\section{Penicillium and Cladosporium}

Penetration of fungal spores was also estimated from the results of the optical particle counter. Since the chambers did not reach a steady state and only the range of the particle diameter was known, the penetration rate was estimated as a percentage of the particles penetrated through the structure, Eq. (5). These percentages are compared to the results of inert particles in Table 4. The results show the same tendency as in the case of inert particles: the penetration rate is strongly dependent on pressure difference, but holes in the surface boards have only minor effect on penetration. 
Table 4 Percentage of the spores penetrated through the structure measured with the optical particle counter compared to the results of inert particles

\begin{tabular}{|l|c|c|c|c|c|}
\hline Floor & Pressure & Inert & Inert & Penicillium & Cladosporium \\
\hline & & $\mathbf{1 . 3} \mathbf{~ m m}$ & $\mathbf{2 . 5} \mathbf{~ m m}$ & $\mathbf{1 . 0 - 5 . 0} \mathbf{~ m m}$ & $\mathbf{1 . 0 - 5 . 0} \mathbf{~ m m}$ \\
\hline No penetrations & high* & 3.20 & 1.60 & 0.79 & 1.16 \\
\hline Ø13 mm holes in the surfaces & low** & 1.00 & 0.70 & 0.17 & 0.42 \\
\hline & high* & & & 0.70 & 0.63 \\
\hline
\end{tabular}

* high pressure $20 \mathrm{~Pa}$ for inert particles and $18 \mathrm{~Pa}$ for fungal spores

** low pressure $6 \mathrm{~Pa}$ for both inert particles and fungal spores

Most of the spores of Penicillium were impacted at stage 4 of the Andersen impactor corresponding mean geometric diameter of $2.6 \mu \mathrm{m}$. Spores of Cladosporium were mainly impacted at stages 4 and 5 corresponding mean geometric diameters of $2.6 \mu \mathrm{m}$ and $1.4 \mu \mathrm{m}$.

During the test of Cladosporium, which was carried out 21 hours after the test of Penicillium, the spores of Penicillium were still detected. According to optical particle counter, the levels of particles were low, but spores of Penicillium were still detected with Andersen impactor in all measurements with Cladosporium. Supplying the spores was problematic causing too high concentrations in $\mathrm{CH} 2$, resulting with all samples from $\mathrm{CH} 2$ overcrowded after cultivation of impactor plates. Thus, the results shown in Table 5 are only indicative estimates and the real values may be lower due to higher concentrations in $\mathrm{CH} 2$ than was possible to measure with the impactor. The penetration rates calculated in percentages show again a strong dependency of pressure difference. In chamber 1 (indoor) the results between optical particle counter and Andersen impactor correlated well, correlation factor 0.93 . However, for the chamber 2 the correlation factor was only 0.60 , which was due to overcrowded results with Andersen impactor in chamber 2.

Table 5 Penetration of spores (\%) of Penicillium and Cladosporium from $\mathrm{CH} 1$ to $\mathrm{CH} 2$ detected with Andersen impactors

\begin{tabular}{|l|c|c|c|c|}
\hline Floor & Pressure & Supply of Penicillium & \multicolumn{2}{|c|}{ Supply of Cladosporium } \\
\hline & $(\mathrm{Pa})$ & $\begin{array}{c}\text { Detected } \\
\text { Penicillium }\end{array}$ & $\begin{array}{c}\text { Detected } \\
\text { Cladosporium }\end{array}$ & $\begin{array}{c}\text { Detected } \\
\text { Penicillium }\end{array}$ \\
\hline No penetrations & 18 & 5.64 & 24.08 & 1.10 \\
\hline Ø13 mm holes in the surfaces & 18 & 1.44 & 5.32 & 0.20 \\
\hline & 6 & - & 49.81 & 1.17 \\
\hline
\end{tabular}

\section{DISCUSSION}

The equation of penetration factor (1) applies for inert particles. A possible source of uncertainty in inert particle calculation is the assumption that the penetration through all other parts of $\mathrm{CH} 1$, except the studied structure, is zero. This was avoided by careful tightening of $\mathrm{CH} 1$. The estimation of penetration of fungal spores is more complicated since they can agglomerate and some of them may stick on the surfaces. Furthermore, the shape of microbes is not always spherical. As the measured results were indicative for fungal spores (steady state was not achieved), more detailed analyses should be carried out in further studies.

Another potential source of error relates to the assumption that the air in the chambers is well mixed. The concentrations in $\mathrm{CH} 2$ were measured in three different heights to check the mixing. The concentration of $\mathrm{CH} 1$ (indoor) was measured near the exhaust point. The error due to the possible lack of complete mixing was most probably minor since the measurements were well repeatable.

Estimation of the penetration factor with the described method is strongly dependent on deposition velocity. In this study, the used deposition velocity was a combination of measurements and theoretical assumption from studies (Xu et al. 1994, Thatcher et al. 2002, Lai and Nazaroff 2000). The penetration factor was also calculated with other deposition velocities measured in similar chambers. Recent studies on particle deposition to indoor surfaces make it clear that the deposition rate varies broadly across conditions. Particle size is undoubtedly important. However, other factors can also influence the deposition rate significantly including interior 
furnishing (quantity and type of the surface) and the indoor air movement. According to Thatcher et al. (2002) the air movement from zero to $0.142 \mathrm{~m} / \mathrm{s}$ (which is a typical air velocity indoors) increased the deposition rate by $15 \%$ for $1 \mu \mathrm{m}$ particles and by $24 \%$ for $1.9 \mu \mathrm{m}$ particles. Furnishing had a great impact deposition rate; deposition rate increased over $100 \%$ for $1 \mu \mathrm{m}$ particles at air velocity $0.054 \mathrm{~m} / \mathrm{s}$ and $78 \%$ for $2.5 \mu \mathrm{m}$ if the empty room was furnished (Thatcher et al. 2002). The highest deposition rates had been reported mainly from field settings (Abt et al. 2000, Long et al. 2001, Vette et al. 2001), where the control of experimental settings is limited. Even in the best conditions it is difficult to isolate deposition from the many competing factors that can influence airborne particle concentrations. Although the penetration factor estimated in this study varied a lot depending on the deposition velocity it still clearly stated the fact that the penetration occurred even at lower pressure difference and that the penetration was highly dependent on the pressure difference.

In recent studies (Liu and Nazaroff 2001, Mosley et al. 2001, Vette et al. 2001), penetration factors of particles within range of $0.5-2.5 \mu \mathrm{m}$ have been between 0.5 and 1 depending on the dimensions of studied cracks. These results cover the size distribution of fungal spores; and the peak of spores of 1-2 $\mu \mathrm{m}$ seems to be very capable for penetration if the crack height is higher than $0.1 \mathrm{~mm}$ (Liu and Nazaroff 2003). Liu and Nazaroff (2001) have estimated that the penetration through mineral wool insulation is negligible. In our study mineral wool was inside the structure, and as the results showed penetration occurred, since the installation of mineral wool is seldom perfect allowing some routes for particles. Current study shows that penetration through the tested real structure took place. The penetration factors determined are significantly different than in former studies indicating that surface contacts of mineral wool and other building elements are likely to have important effect on the penetration. The importance of surface contacts seems to be confirmed by tests; e.g. for $1.3 \mu \mathrm{m}$ particles the penetration factor at $20 \mathrm{~Pa}$ was 0.19 when the boards didn't have any penetration and 0.15 when the four $10 \mathrm{~mm}$ holes on the surfaces were open, when the pressure was decreased to $6 \mathrm{~Pa}$ the penetration factors were 0.08 and 0.03 respectively. Thus, the holes on the surface boards did not have any effect on the measured penetration of particles but probably the small leakage routes between surface contacts of mineral wool and other building elements.

The results of the study address an important question for design and construction of buildings because determined penetration factors of 0.05 to 0.2 will cause high concentrations already at moderate pressure difference. It seems that penetration of fungal spores is difficult to control by sealing and by controlling the air tightness of the building envelope. The only effective way to avoid penetration is pressurizing the building. This study showed significant difference between 6 and $20 \mathrm{~Pa}$ under-pressure, and it is obvious that pressurization will prevent the penetration. In hot climates, in buildings equipped with air conditioning pressurization is often used for avoiding moisture convection and condensation in structures. These buildings are probably microbiologically safe as air flow through structures is possible only for very short time during wind pressure peaks. In cold climates, the situation is completely different due to reverse direction of moisture flow - here pressurization may cause condensation in structures. Thus, balanced ventilation is recommendable in cold climates for decreasing the risk of penetration, and if buildings are pressurized it should be taken into account in designing structures.

\section{CONCLUSION}

This study carried out particle transport measurements for full-scale timber frame structure similar to a wooden floor. Measurements at moderate pressure differences allowed determining penetration factors within the range of 0.05 to 0.2 for inert particles and indicative results with fungal spores confirmed the penetration through the structure. Both measurements showed that the penetration was highly dependent on pressure difference and not dependent on holes in surface boards of the structure. The results are likely to show that surface contacts of mineral wool with other building elements may have an important role on the penetration.

The penetration was roughly the same within particle size range of $0.6-2.5 \mu \mathrm{m}$, but particles $\geq 4.0 \mu \mathrm{m}$ did not penetrate at all even at higher-pressure difference of $20 \mathrm{~Pa}$. Direct flow-path through $15 \mathrm{~mm}$ pipe caused the penetration of $4.0 \mu \mathrm{m}$ particles and increased penetration factor of smaller particles up to 1.0.

Results have important consequences for practical design showing that penetration of fungal spores is difficult to control by sealing the building envelope. Because the holes in the surface boards didn't effect on the measured penetration factors, the only effective way to avoid penetration seems to be balancing or even pressurizing the building. However, in cold climates moisture condensation risk should be taken into account. Determined penetration factors were highly dependent on pressure difference. This indicate mechanical exhaust ventilation 
causing under pressure in the building may cause health risk if there exists some contamination in the building envelope.

\section{ACKNOWLEDGEMENTS}

The foundation of the Chancellor Paavo Uronen of the Helsinki University of Technology is gratefully acknowledged for sponsoring this project.

\section{REFERENCES}

Abt E., Suh H.H., Catalony P., Koutrakis P., 2000, Relative contribution of outdoor and indoor prticle sources to indoor concentrations, Environmental Science and Technology, 34, pp. 3579-3587

Adabie M., Limam K., Allard F., 2001, Indoor particle pollution: effect of wall textures on particle deposition, Building and Environment, 36: 821-827

Airaksinen M., Pasanen P., Kurnitski J., Seppänen O., Microbial contamination of indoor due leakages from crawl space, accepted for publication in Indoor Air 14.4.2003

Andersen A.A., 1958, New sampler for the collection, sizing, and enumeration of viable airborne particles. Journal of Bacteriology, 76:471-484.

Andersen Samplers, Inc. 1979. Operation Manual for Andersen Sampler, Viable (microbial) Particle Sizing Sampler, Atlanta, GA, U.S.A.

Beneš M., Holub R.F., 1996, Aerosol wall deposition in enclosures investigated by means of a stagnant layer, Environment International, 22, Suppl.1, pp. S883-889

Cheng Y. S., 1997, Wall deposition of radon progeny and particles in a spherical chamber, Aerosol Science and Technology, 27, pp. 131-146

Crump J.G., Seinfield J.H., 1981, Turbulent deposition and gravitational sedimentation of an aerosol in a vessel of arbitrary shape, Journal of Aerosol Science 12:405-415

DeKoster J A., Thorne P S., 1995, Bioaerosol concentrations in noncomplaint, complaint and intervention homes in the Midwest, American Industrial Hygiene Association Journal, 56, pp. 573-580

EN 13829, 2000, Thermal performance of buildings. Determination of airpermeability of buildings. Fan pressurization method. (ISO 9972:1996, modified)

Fisk W. J., Faulkner D., Palonen J., Seppänen O., 2002, Performance and Costs of Particle Air Filtration Technologies, Indoor Air Vol 12 (4): 223-234

Fogh C. L., Byrne M. A., Roed J., Goddard A. J. H., 1997, Size specific indoor aerosol deposition measurements and derived I/O concentrations ratios, Atmospheric Environment 31, pp. 2193-2203.

Ellringer P J., Boone K., Hendrikson S., 2000, Building materials used in construction can effect indoor fungal levels greatly, Am Ind Hyg Assoc J 61:895-899

Hunter C A., Grant C., Flannigan B., Bravery A F, 1988, Mould in buildings: the air spore of domestic dwellings, Int Biodeter 24:81-101

Hyvärinen A., 2002, Characterizing moisture damaged buildings - Environmental and biological monitoring, Academic Dissertation, University of Kuopio, Finland.

Katsouyanni K., Touloumi G., Samoli E., Gryparis A., LeTertre A., Monopolis Y., Rossi G., Zmirou D., Ballester F., Boumghar A., Anderson H.R., Wojtyniak B., Paldy A., Braunstein R., Pekkanen J., Schindler C., Schwartz J.,2001, Confounding and effect modification in the short-term effects of ambient particles on total mortality: Results from 29 European cities within the APHEA2 project, Epidemiology, 12 , pp. 521-531

Kulmala M., Asmi A., Pirjola L., 1999, Indoor air aerosol model: the effect of outdoor air, filtration and ventilation on indoor concentrations, Atmospheric Environment 33 (1999) 2133-2144.

Kuo Y-M., Li C-S, 1994, Seasonal fungus prevalence inside and outside of domestic environments in the subtropical climate, Atmospheric Environment 28 (19), pp. 3125-3130.

Kurnitski J, Pasanen P.2000. Crawl space moisture and microbes, Proceedings of Healthy Buildings 2000, Vol 3, 205-210, Espoo, Finland.

Kurnitski J., Crawl space air change, heat and moisture behavior, Energy and Buildings, 2000, 32, pp. 19-39.

Laden F., Neas L.M., Dockery D.W., Schwarz J., 2000, Association of fine particulate matter from different sources with daily mortality in six U.S. cities, Environ Health Perspect 108:941-947

Lai A.C.K., Nazaroff W.W., 2000, Modelling indoor particle deposition from turbulent flow onto smooth surfaces, J. Aerosol Sci., 31, 463-476.

Lai A.C.K., 2002, Particle deposition indoors: a review, Indoor Air 12:211-214. 
Lai A.C.K., Byrne M.A., Goddard A.J.H., 2002, Experimental Studies of the Effect of Rough Surfaces and Air Speed on Aerosol Deposition in a Test Chamber, Aerosol Science and Technology, 36:973-982

Li C-S., Kuo Y-M., 1994, Characteristics of airborne microfungi in subtropical homes, The Science of the Total Environment, 155, pp. 267-271.

Liu D-L., Nazaroff W.W., 2001, Modelling pollutant penetration across building envelopes, Atmospheric Environment 35, pp. 4451-4462.

Liu D-L., Nazaroff W.W., 2003, Particle penetration through building cracks, submitted to Aerosol Science and Technology, 37, pp. 565-573.

Long C.M., Suh H.H., Catalony P.J., Koutrakis P., 2001, Using time- and size-resolved particulate data to quality indoor penetration and deposition behavior, Environmental Science and Technology, 35, pp. 20892099.

Macher J M., Huang F-Y., Flores M., 1991, A two-year study of microbiological indoor air quality in a new apartment, Archives of Environmental Health 46(1), pp. 25-29.

Mattson J., Carlson OE., Engh I B., 2002, Negative influence on IAQ by air movement from mould contaminated constructions into buildings, Proceedings of Indoor Air 2002, Vol.1, pp. 764-769, Monterey, California, USA.

Mosley R. B., Greenwell D.J., Sparks L. E., Guo Z., Tucker W. G., Fortmann R., Whitfield C., 2001, Penetration of Ambient Fine Particels into the Indoor Environment, Aerosol Science Technology 34, pp. 127-136.

Nevalainen A., Partanen P., Jääskeläinen E., Hyvärinen A., Koskinen O., Meklin T., Vahteristo M., Koivisto J., Husman T., 1998, Prevalence of moisture problems in Finnish houses, Indoor Air 4:45-49.

Nevalainen A., Pasanen A-L., Niininen M., Reponen T., Kalliokoski P., 1991, The indoor air quality in Finnish homes with mould problems, Environ Int 17:299-302

Nguyen Thi L. C., Kerr G., Johanson J., 2000, Monitoring and remediation after a flood in a Canadian office building, Proceedings in Healthy Building 2000, Vol. 3, pp. 433-438.

Nomura Y., Hopke P.K., Fitzgerald B., Mesbah B., 1997, Deposition of particles in a chamber as a function of ventilation rate, Aerosol Science and Technology, 27, pp. 62-72

Pasanen P., Kolari S., Pasanen A-L., Kurnitski J., 2001. Fungal Growth on Wood Surfaces at Different Moisture Conditions in Crawl Spaces. Proceedings of conference IAQ2001, Moisture, microbes and Health Effects; Indoor air quality and moisture in Buildings. ASHRAE, Atlanta.

Peat JK., Dickerson J., Li J., 1998, Effects of damp and mould in the home on respiratory health: a review of the literature, Allergy 53(2), pp.120-128.

Persily A.K., 1998, Air tightness of Commercial and Institutional Buildings: Tight Buildings, Thermal Envelopes, VII Conference, Clearwater FL, USA

Reponen T., Nevalainen A., Jantunen M., Pellika M., Kalliokoski P., 1992, Normal range criteria for indoor air bacteria and fungal spores in subarctic climate, Indoor Air 1992, Vol2, pp. 26-31.

Reponen T., 1995, Aerodynamic diameters and respiratory deposition estimated of viable particles in mold problem dwellings, Aerosol Science Technology 22(1), pp. 11-23.

Samet J.M., Zeger S.L., Dominici F., Curriero F., Coursac I., Dockery D., Schwarz J., Zanobetti A., 2000, The national morbidity and mortality and air pollution study, Moridity and mortality from air pollution in the United States, Res Rep Health Eff Inst 94(pt2):5-70.

Thatcher T.L. Lai, A.C.K., Moreno-Jackson R., Sextro R.G., Nazaroff W.W., 2002, Effects of room furnishings and air speed on particle deposition rates indoors, Atmospheric Environment, 36, pp. 1811-1819.

Tiittanen P., Timonen K. L., Ruuskanen J., Mirme A., Pekkanen J., 1999, Fine particulate air pollution, resuspended road dust and respiratory health among symptomatic children, European Respiratory Journal, 13 pp. $266-273$.

Verhoeff AP., Burge HA., 1997, Health risk assessment of fungi in home environments, Ann Allergy Asthma Immunol 78, pp. 544-556.

Vette A.F., Rea A.W., Lawless P.A., Rodes C.E., Evans G., Highsmith V.R., Sheldon L., 2001, Characterization of Indoor-Outdoor Aerosol Concentration Relationships during the Fresno PM Exposure Studies, Aerosol Science and Technology 34, pp. 118-126.

Xu M., Nematollahi M., Sextro R.G., Gadgil A.J., Nazaroff W.W., 1994, Deposition of tobacco smoke particles in a low ventilation room, Aerosol Sci. Technol., 20, 194-206. 